\title{
Mathematical modelling of lemon verbena leaves drying in a continuous flow dryer equipped with a solar pre-heating system
}

\author{
S. Soodmand-Moghaddam ${ }^{1}$, M. Sharifi ${ }^{1}$, H. Zareiforoush ${ }^{2}$, and H. Mobli ${ }^{1}$ \\ ${ }^{1}$ Department of Agricultural Machinery Engineering, Faculty of Agricultural Engineering and Technology, University of \\ Tehran, Karaj, Iran; ${ }^{2}$ Department of Mechanization Engineering, Faculty of Agricultural Sciences, University of Guilan, \\ Rasht, Iran
}

Corresponding Author: M. Sharifi, m.sharifi@ut.ac.ir

Received: 18 August 2019 / Accepted: 24 December 2019 / Published: 14 January 2020

(c) 2020 Codon Publications

OPEN ACCESS CC)(1)(2)

RESEARCH ARTICLE

\begin{abstract}
The modelling of the drying process of lemon verbena leaves in a continuous flow dryer equipped with a solar pre-heating system was performed at three levels of drying temperature $\left(50,40\right.$, and $\left.30{ }^{\circ} \mathrm{C}\right)$ and three levels of air velocity $(2,1.5$ and $1 \mathrm{~m} / \mathrm{s})$. During the experiments, lemon verbena leaves were dried to the final moisture content of 10 from $76 \%$ wet basis in the continuous flow dryer. Drying kinetic showed to drying temperature and air velocity exerted significant influence on the drying time. Also, the dried lemon verbena leaves quality was obtained by determining the essential oil content of the product after drying in different conditions in the dryer. Finally, it was observed that the highest essential oil content was maintained at a temperature of $40{ }^{\circ} \mathrm{C}$ and air velocity of $1 \mathrm{~m} / \mathrm{s}$. Suitability of 10 different mathematical drying models was used to describe drying lemon verbena leaves in this dryer. The results have shown that Midilli and Kucuk's model can successfully predict the experimental data in all air temperatures and air velocities. In Midilli and Kucuk's model, the amounts of $R^{2}$ were above $999 \times 10^{-3}$ and the amounts of root- mean-square error (RMSE) and chi-square $\left(\chi^{2}\right)$ were less than $174 \times 10^{-4}$ and $19 \times 10^{-4}$.
\end{abstract}

Keywords: air velocity, air temperatures, drying kinetic, Midilli and Kucuk's model

\section{Introduction}

Lemon verbena (Lippia citriodora Kunth.) is one of the wellknown medicinal plants that has many properties, including antispasmodic, carminative, diuretic, digestive and sedative agent (da Cunha et al., 2012). The most important constituents of lemon verbena essential oil (EO) include neral, limonene and geranial (Ishkeh et al., 2019). The most important process for keeping medicinal plants is drying. Drying is one of the methods of food storage (Javed et al., 2019). The drying methods of medicinal plants have a great influence on their quality (Asekun et al., 2007). Therefore, it is important to choose the suitable drying methods for sensitive products, such as medicinal plants (Motevali et al., 2014).

Reducing moisture content (MC) reduces or stops the enzymatic or microbial activity and reduces the weight of products and facilitates the processing of products. Factors such as temperature and velocity of inlet air, initial and final humidity of the product, relative humidity and ambient air temperature affect the amount of moisture variation relative to time (Movagharnejad and Nikzad, 2007). In a research, the drying of lemon balm leaves in an indirect mode solar dryer with a double-pass air heater was investigated. According to the tests results, the temperature difference between the collector outlet and ambient declined significantly with increasing volumetric flow rate, whereas increasing the flow rate improved the collector thermal efficiency by $\sim 20 \%$ (Shamekhi-Amiri et al., 2018).

A common method for predicting moisture loss during drying time is the empirical modelling or regression modelling, which normally measures different variables by 
performing empirical experiments, and the best algebraic equation between variables is selected based on the fitting of the measured data with known algebraic equations related to the kinetics of drying. Modelling the actual process of drying in terms of mathematical relations is necessary to define optimum drying conditions (Panchariya et al., 2002). Akpinar (2010) fitted the thin-layer drying data in a solar dryer with forced convection and under the open sun with natural convection of mint leaves to 10 different mathematical models. Wang and Singh's model was found as the best model describing the thin layer drying behaviour of mint leaves (Akpinar, 2010).

In a study, 14 mathematical models of mint and thymus thin layer drying were tested to specify the suitable model in an indirect-mode forced convection solar dryer. The Midilli and Kucuk's model and Page and modified Page models were found for describing the drying curves of the mint and thymus, respectively (El-Sebaii and Shalaby, 2013).

Aral and Beşe (2016) investigated the thin-layer drying characteristics of hawthorn fruit in a convective dryer at different air temperatures and air velocities. The results of this study showed that drying time decreases with increasing air temperature and air velocity. Also, Midilli et al's model was obtained as the best model for drying behaviour in this study (Aral and Beşe, 2016).

Jayatunga and Amarasinghe (2018) examined the drying kinetics of black pepper in a conventional spouted bed dryer and a spouted bed dryer fitted with a non-porous draft tube. Their results showed that the highest drying rate was achieved when black pepper was dried without draft tube at the highest drying temperature. Also, a new thin layer drying model was proposed and compared with five commonly used models and the drying behaviour of black pepper in spouted bed dryer was best fitted to (Verma et al., 1985) model and the proposed model (Jayatunga and Amarasinghe, 2018). In a study, seven different mathematical drying models were compared for describing thin layer drying of cashew kernels in a batch dryer. The results showed that the Page model was found to be the best for describing the drying behaviour of cashew kernels (Asiru et al., 2013).

Knowing the drying behaviour is important in designing, simulating and optimising the drying process. Several studies have been conducted on the drying of agricultural products, including vegetables, such as drying savory leaves (Arslan and Özcan, 2012), drying turmeric rhizomes in a solar conduction dryer (Borah et al., 2015) and drying of thyme (Thymus Vulgaris L.) (Doymaz, 2011). Drying kinetic study is necessary to obtain information about the time required for drying and select the appropriate drying model (Baini and Langrish, 2008).
Due to the possibility of undesirable changes in the quality of food because of drying, its control is of particular importance; therefore, in order to maintain the safety of products, their moisture should be reduced to a certain amount. To achieve this goal, it is necessary to model the drying of various agricultural products so that the model of drying out the product can be predicted based on the pattern obtained from the model.

As conventional methods of drying leaves plants have many problems, such as lower product quality, in this article we used a continuous flow dryer. In this type of dryer, two sources of solar energy and natural gas were used to provide heat. Due to the importance and sensitivity of the lemon verbena medicinal plant to drying, the aim of this study was to develop a continuous dryer equipped with a solar pre-heating system, to find out the suitable model and to describe the drying characteristics of lemon verbena leaves in different air temperatures and air velocities.

\section{Materials and methods}

\section{Material}

Lemon verbena leaves were directly bought from local producers in Rasht, Iran. Leaves were packed in polyethylene packaging and stored in a refrigerator at a temperature of $6^{\circ} \mathrm{C}$. The initial MC of the samples was determined by placing three samples of leaves in a hot air oven at a temperature of $103{ }^{\circ} \mathrm{C}$ for $24 \mathrm{~h}$ (Zheng et al., 2005). The average initial MC of the lemon verbena leaves was equal to $76 \%$ wet basis (w.b.).

\section{Experimental procedure}

Drying experiments were performed in a continuous dryer equipped with a solar pre-heating system at the Renewable Energy Site of the University of Guilan, Rasht, Iran $\left(49^{\circ} 35^{\prime} 19^{\prime \prime} \mathrm{E}\right.$ longitude and $37^{\circ} 16^{\prime} 33^{\prime \prime} \mathrm{N}$ latitude). The dryer consists of air relative humidity/temperature sensors, solar water heater, gas water heater, continuous flow dryer, heat exchanger, water pump and centrifugal air blower (Figure 1). The air temperature and relative humidity in the drying chamber were measured by an air relative humidity/temperature sensor (Model AM2301, China).

The variation of the recorded temperatures from the set points during the experiments was $\pm 1{ }^{\circ} \mathrm{C}$. The air velocity of the input air was measured by a turbine-type anemometer (Lutron Model, 80 AM, Taiwan). The dryer was a continuous flow type with four sets of conveyor belts placed above each other. The speed of the conveyor belt was adjusted using a single-phase inverter (LG Model IC5, Korea). Based on some pretests, the speed of the conveyor was adjusted to $43.1 \times 10^{-2} \mathrm{~m} / \mathrm{s}$. 


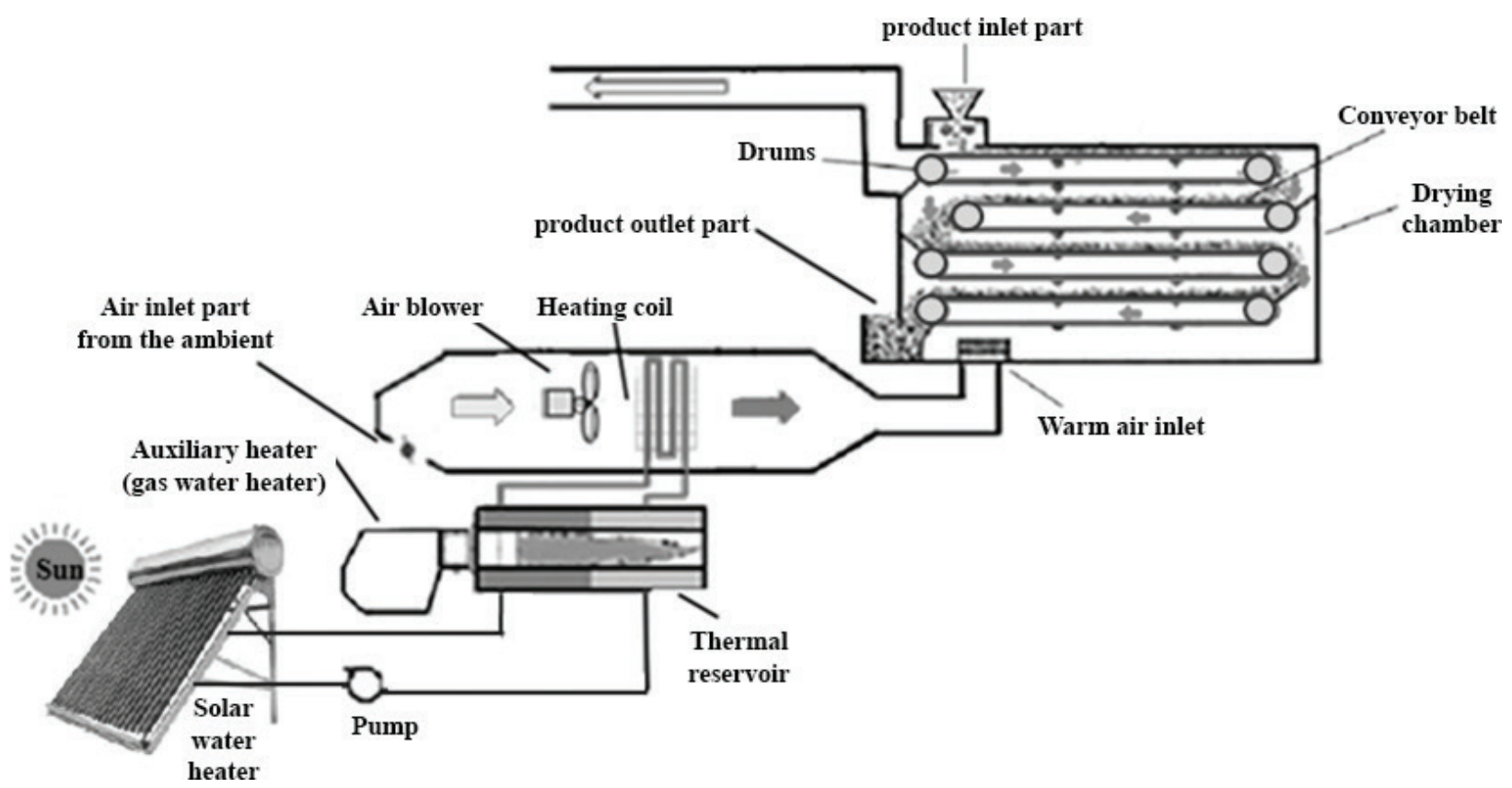

Figure 1. Schematic view of the continuous dryer equipped with solar pre-heating system.

The movement of the drive pulley of the conveyor belts was performed by an electric motor $(0.75 \mathrm{~kW})$. For the production of hot air and drying, the product is used in conventional dryers from the thermal energy of a gas burner. A solar water heater combined with a gas water heater (Butane Model 3318IF, Iran) was used to heat the water. The heated water was then entered into a heat exchanger (Hepaco Model HP-1500, Iran) using pipelines. The airflow was blown into the water pipe by a blower to direct the heat of the pipes into the drying chamber. A portion of the required thermal energy was provided by a thermosiphon type of solar water heater having the capacity of $150 \mathrm{~L}$. The four rows of conveyor belts moved in the opposite direction in the drying chamber (with dimensions of $150 \times 150 \times 80$ $\mathrm{cm}^{3}$ ). The centrifugal blower was able to change the amount of inlet air by a single-phase inverter (LG Model IC5, Korea).

After the dryer reached desired conditions, about $150 \mathrm{~g}$ of the samples was put into the dryer chamber for drying. Eventually, the MC of the lemon verbena reached 10\% (w.b.) for each experiment. In this research, drying of the product was performed at 30,40 and $50{ }^{\circ} \mathrm{C}$ temperatures and air velocities of 2, 1.5 and $1 \mathrm{~m} / \mathrm{s}$. The leaves were weighed (every $10 \mathrm{~min}$ ) by a digital balance (A\&D Model GF6000, Japan).

\section{Drying calculation}

The $\mathrm{MC}$ and moisture ratio of lemon verbena leaves samples during drying experiments was calculated using the following equations (Omolola et al., 2018; Erenturk et al., 2004):

$M C_{w . b}=\frac{W_{a}-W_{b}}{W_{a}}$
$M R=\frac{M_{t}-M_{e}}{M_{o}-M_{e}}$

where $M C, W_{o}$ and $W_{d}$ are the $\mathrm{MC}(\%)$, weight (g) of the sample and dried sample, respectively, and $M_{t}$ and $M_{o}$ are the $\mathrm{MC}$ at any drying time and the initial $\mathrm{MC}$, respectively. This equation can be simplified to $M_{t} / M_{o}$ because the equilibrium $\mathrm{MC}$ value $\left(M_{e}\right)$ is small compared with that of $M_{t}$ and $M_{o}$ (Essalhi et al., 2018; Rabha et al., 2017). Also, Equation (3) was used to calculate the drying rate during leaves drying experiments (Labed et al., 2016).

$D R=\frac{\left(M_{t+d t}-M_{t}\right)}{d_{t}}$

\section{Extraction of the EO}

Medicinal plants have unique and valuable properties. EO derived from medicinal plants had long been used in the food, pharmaceutical, perfume and cosmetics industries (Sari, 2018). One of the most important methods of preserving medicinal plants is drying (Bhardwaj et al., 2019). The method and temperature of drying of these plants have a great influence on their EO content and quality. For this reason, in the present study, the amount of EO of lemon verbena leaves after drying was obtained for each sample at different drying temperatures and speeds.

For EO extraction by the hydro-distillation method, $30 \mathrm{~g}$ of each sample was placed into a Clevenger with $450 \mathrm{ml}$ of water for $3 \mathrm{~h}$ (Abd El-Gaber et al., 2018). Isolation of EO from water due to density difference was easy (Saleh 
et al., 2019). The EO content of each sample after weighing by a digital balance was calculated using Equation (4).

$$
\text { Essential oil content }(\%)=\frac{E O(g)}{\operatorname{Dry} \cdot \operatorname{matter}(g)} \times 100
$$

\section{Mathematical modelling}

Ten drying equations given in Table 1 were evaluated to select the most suitable model for describing the drying curves of lemon verbena leaves. Regression analysis was performed using MATLAB and SPSS 11.5.1 software package. In order for the superior model to be chosen, the value of the coefficient of determination must be high and the value of RMSE and $\chi^{2}$ must be low (Torki-Harchegani et al., 2016). The calculations were performed using Equations (5), (6) and (7) (Akpinar, 2010):

$$
\begin{aligned}
& R^{2}=\frac{\sum_{i=1}^{N}\left(M R_{i}-M R_{p r e, i}\right) \sum_{i=1}^{N}\left(M R_{i}-M R_{\text {exp }, i}\right)}{\sqrt{\left[\sum_{i=1}^{N}\left(M R_{i}-M R_{p r e, i}\right)^{2}\right] \cdot\left[\sum_{i=1}^{N}\left(M R_{i}-M R_{\text {exp }, i}\right)^{2}\right]}} \\
& R M S E=\left[\frac{1}{N} \sum_{i=1}^{N}\left(M R_{p r e, i}-M R_{\text {exp }, i}\right)^{2}\right]^{\frac{1}{2}} \\
& x^{2}=\frac{\sum_{i=1}^{N}\left(M R_{\text {exp }, i}-M R_{p r e, i}\right)^{2}}{N-n}
\end{aligned}
$$

where $M R_{\text {pre. }}$ and $M R_{\text {exp, } i}$ are the predicted and experimental moisture ratio, respectively, and $n$ and $\mathrm{N}$ are the number of the drying constants and observations, respectively.

Table 1. Mathematical models applied to the moisture ratio curves.

\begin{tabular}{lll} 
Models & Equations & References \\
\hline $\begin{array}{l}\text { Two-term } \\
\text { exponential } \\
\text { Henderson } \\
\text { and Pabis }\end{array}$ & $M R=a \cdot e^{(-k t)}+(1-a) \cdot e^{(-k a t)}$ & Badaoui et al. (2019) \\
$\begin{array}{l}\text { Logarithmic } \\
\text { Diffusion }\end{array}$ & $M R=a \cdot e^{(-k t)}$ & Mghazli et al. (2017) \\
$\begin{array}{l}\text { approach } \\
\text { Midilli and }\end{array}$ & $M R=a \cdot e^{(-k t)}+c$ & Motevali et al. (2016) \\
Kucuk & $M R=a \cdot e^{(-k t)^{n}}+b t$ & Vijayan et al. (2016) \\
Newton & $M R=e^{(-k t)}$ & El-Sebaii and Shal- \\
& & aby (2013) \\
Modified & $M R=e^{\left(-(k t)^{n}\right)}$ & Yogendrasasidhar \\
Page & and Setty (2018) \\
Two-term & $M R=a \cdot e^{(-k t)}+b \cdot(-k t)$ & Duffie and Beckman \\
& (2013) \\
Page & $M R=e^{\left(-k t^{n}\right)}$ & (Torki-Harchegani \\
Wang and & $M R=1+a t+b t^{2}$ & et al. (2016) \\
Singh & Vijayan et al. (2016) & Aregbesola et al. \\
& & (2015) \\
\hline
\end{tabular}

\section{Results and discussion}

\section{Drying kinetics}

Lemon verbena leaves were dried to in a continuous dryer equipped with a solar pre-heating system at different temperatures $\left(30,40\right.$ and $\left.50{ }^{\circ} \mathrm{C}\right)$ and different air velocities $(2,1.5$ and $1 \mathrm{~m} / \mathrm{s})$. Experimental data obtained from the drying process of lemon verbena leaves were converted into MC. The MC diagram of the lemon verbena leaves during the drying period is shown in Figure 2. From the figure, it is clear that with an increase in the air temperature from 30 to $50^{\circ} \mathrm{C}$, the slope of the $\mathrm{MC}$ curve increases.

Air temperature is an important parameter in drying the products. Therefore, with increasing air temperature, the moisture removal increased and, as shown in Figure 3 , the drying time also significantly decreased (Akhondi et al., 2011; Mujaffar and John, 2018). It was also observed that with an increase in the air velocity from 1 to $2 \mathrm{~m} / \mathrm{s}$, the drying time decreased. As shown in Figure 3, the minimum drying time of leaves (110 $\mathrm{min}$ ) was obtained at 50 ${ }^{\circ} \mathrm{C}$ and an air velocity of $2 \mathrm{~m} / \mathrm{s}$. The temperature and air velocity of the drying have a great influence on the drying time of the product (Ertekin and Yaldiz, 2004). With increasing air velocity, the moisture transfer rate increases (Motevali et al., 2010). At air velocity of $2 \mathrm{~m} / \mathrm{s}$ and with an increase in the air temperature from 30 to $50^{\circ} \mathrm{C}$, the drying time reduced by $26.66 \%$, while at air velocities of 1.5 and $1 \mathrm{~m} / \mathrm{s}$, the drying time was reduced by 25 and $23.52 \%$, respectively. With an increase in air velocity from 1 to 1.5 and $2 \mathrm{~m} / \mathrm{s}$, the drying time was reduced by 5.888 and $11.76 \%$, respectively. Drying time is one of the important factors in preserving the quality of medicinal plants.

The resulted MC curves showed that the drying time and the slope of the curved surface are inversely related. At the beginning of the drying process, the speed of moisture loss is higher due to increased moisture release from the inside to the product surface. At the end of the drying period, the leaves are dampened with a milder gradient and ultimately the sample is weighed down the constant (Doymaz et al., 2006).

Figure 4 shows the changes in the drying rate versus $\mathrm{MC}$ at temperatures of 30,40 and $50{ }^{\circ} \mathrm{C}$ and air velocities of 1 , 1.5 and $2 \mathrm{~m} / \mathrm{s}$. The process of leaves drying occurred in the falling rate period.

As shown in the figure, the drying rate increased when the drying air temperature increased, and at air temperature of $50^{\circ} \mathrm{C}$ at all air velocities, the highest drying rate was obtained. The reason for this increase could be the increased heat transfer potential between the drying air and product leaves. 

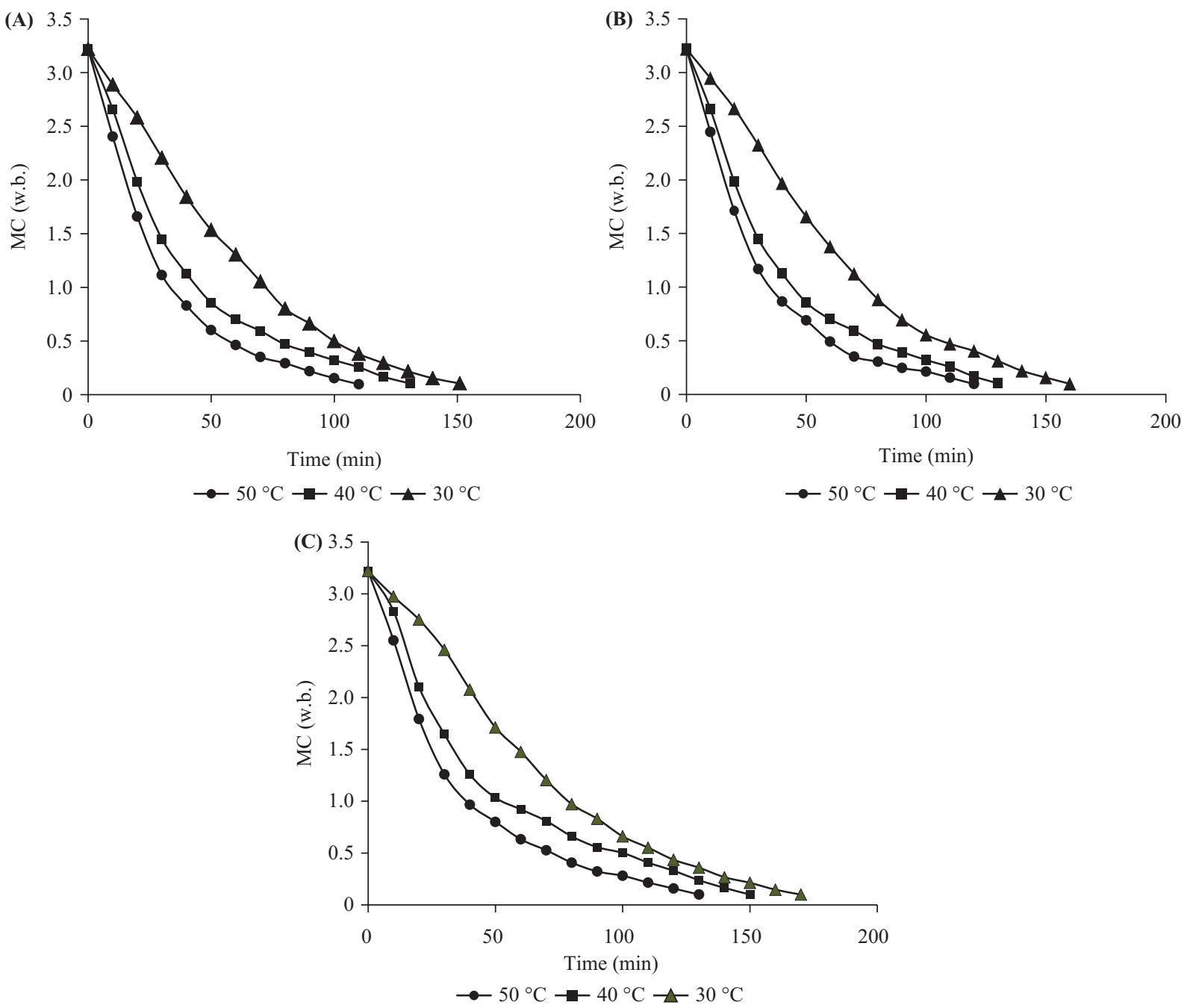

Figure 2. Variation of moisture content as a function of time for different temperatures and air velocities of (A) 2, (B) 1.5 and (C) $1 \mathrm{~m} / \mathrm{s}$.

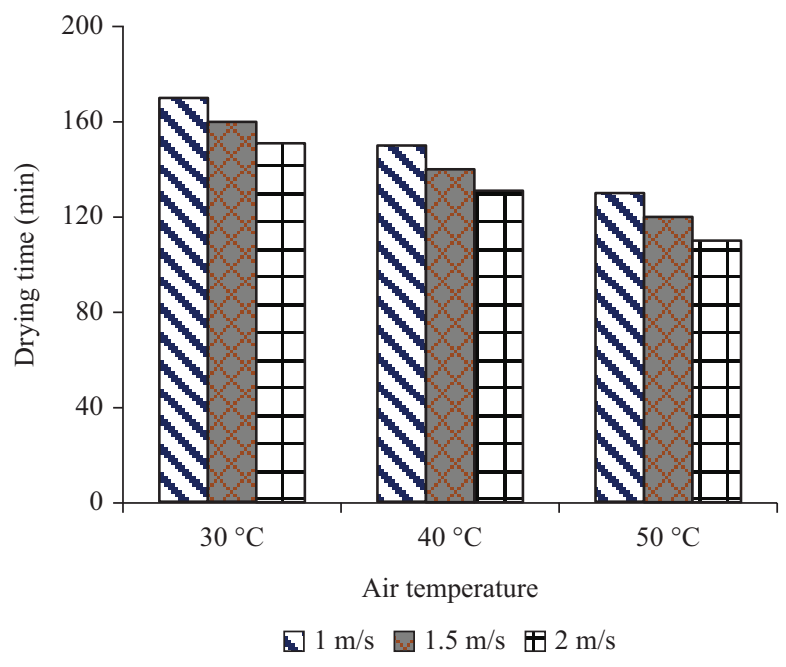

Figure 3. A comparison of the drying time of lemon verbena leaves at different air velocities.

\section{Quality evaluation}

Table 2 shows the effect of three air velocities of $1,1.5$ and $2 \mathrm{~m} / \mathrm{s}$ and temperatures of 30,40 and $50{ }^{\circ} \mathrm{C}$ on the $\mathrm{EO}$ content of lemon verbena leaves. As can be seen from the data in the table, due to the sensitivity of the EO to high temperature, the EO content decreases with increasing temperature.

According to the results, the $\mathrm{EO}$ content at a temperature of $30^{\circ} \mathrm{C}$ was less than that of $40^{\circ} \mathrm{C}$. This may be due to the sudden accumulation of EO in its storage cells. The lowest EO content was obtained at drying temperature of $50{ }^{\circ} \mathrm{C}$ and air velocity of $1 \mathrm{~m} / \mathrm{s}(0.33 \%)$ and the highest $\mathrm{EO}$ content was obtained at drying temperature of $40{ }^{\circ} \mathrm{C}$ and air velocity of $2 \mathrm{~m} / \mathrm{s}(0.60 \%)$. According to the results, drying air temperature and air velocity affected EO content (Pirbalouti et al., 2013; Torki-Harchegani et al., 2016). 

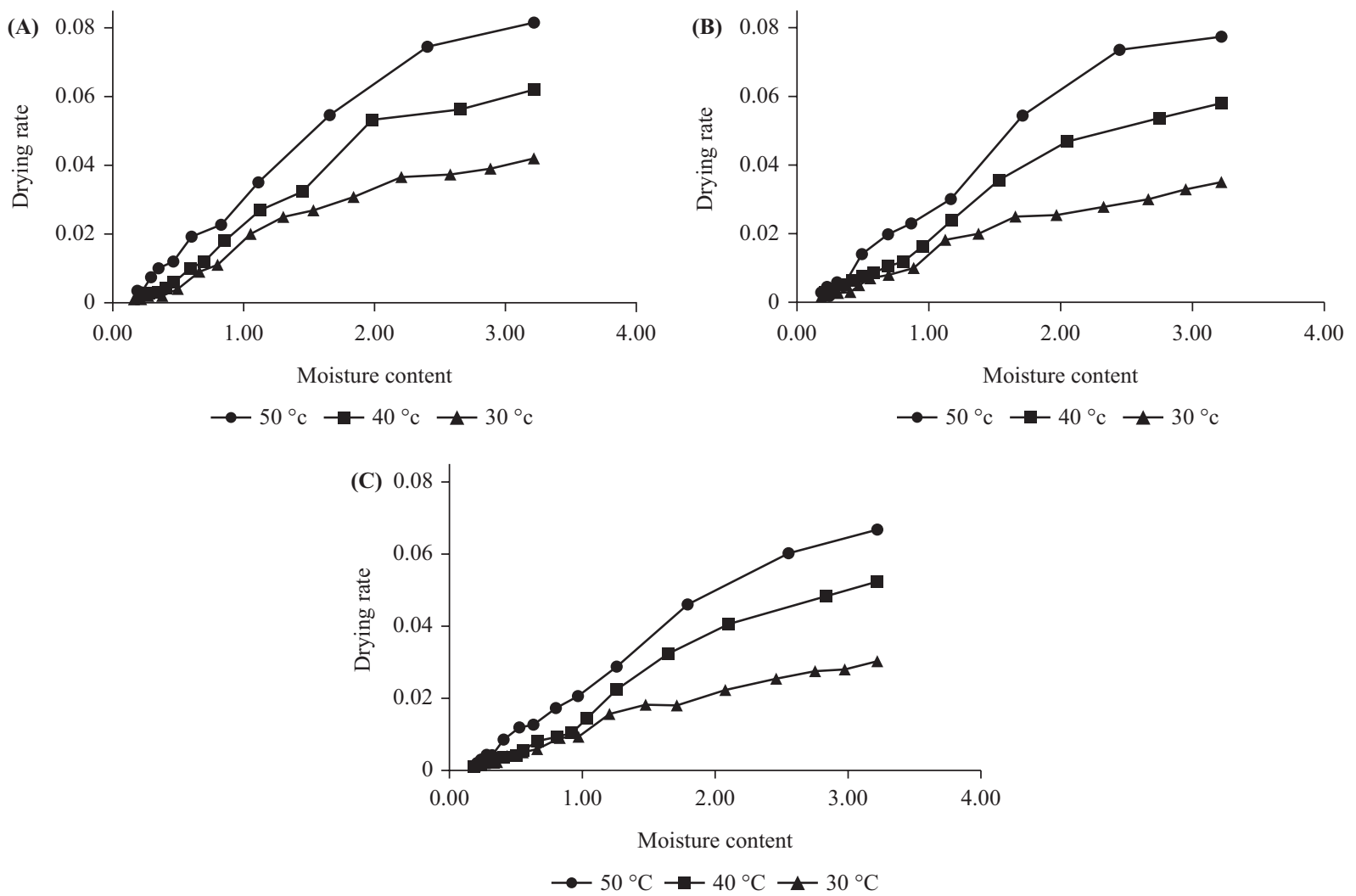

Figure 4. Variation in the drying rate versus moisture content of lemon verbena leaves at air velocities of (A) 2, (B) 1.5 and (C) $1 \mathrm{~m} / \mathrm{s}$.

Table 2.The essential oil content (\%) of lemon verbena leaves at different drying temperatures and air velocities.

\begin{tabular}{lcccc} 
Air velocity $(\mathrm{m} / \mathrm{s})$ & & \multicolumn{3}{c}{ Air temperature $\left({ }^{\circ} \mathrm{C}\right)$} \\
\cline { 1 - 1 } \cline { 5 - 5 } 1 & & 30 & 40 & 50 \\
1.5 & & 0.47 & 0.43 & 0.33 \\
2 & 0.53 & 0.50 & 0.37 \\
& 0.57 & 0.60 & 0.40
\end{tabular}

\section{Mathematical modelling of drying curves}

In this study, different regression models were evaluated with respect to $R^{2}$, RMSE and $\chi^{2}$ values. The criterion for choosing the superior model was a greater amount of $R^{2}$ and lower values of $\chi^{2}$ and RMSE. Table 3 presents the results of statistical indices obtained from different models for lemon verbena drying at different levels of temperature and air velocity. As can be seen from the data, the highest matching with experimental data was obtained in Midilli and Kucuk's model for drying of lemon verbena leaves. The arbitrary constant of this model for all drying conditions (temperature and velocity) is given in Table 4.

The variation of moisture ratio of lemon verbena leaves with time for 2, 1.5 and $1 \mathrm{~m} / \mathrm{s}$ air velocities is shown in
Figure 5. The results have shown that Midilli and Kucuk's model can successfully predict the experimental data. From the plots in the figure, it is observed that Midilli and Kucuk's model exhibits a good fit to the experimental data. Also other researchers have confirmed Midilli and Kucuk's model as the suitable model to describe the drying behaviour of different products, such as drying kinetics of pumpkin slice (Benseddik et al., 2018), yacon slices (Shi et al., 2013), sage leaves in a cabinet dryer (Doymaz and Karasu, 2018) and apple slices (Meisami-Asl et al., 2010).

\section{Conclusions}

In this study, a continuous flow dryer equipped with a solar pre-heating system was used for drying the lemon verbena leaves. The developed system has the proper ability to provide the primary thermal energy for drying lemon verbena leaves. The benefits of using solar energy for drying include reducing pollution emission and fossil fuel consumption. The temperature of the air for drying the lemon verbena was 30,40 and $50{ }^{\circ} \mathrm{C}$ during the experiments, which was sufficient for leaves drying. The increase in drying temperature and air velocity reduced the drying time of lemon verbena leaves. As the air velocity in the dryer increased, the drying rate increased at all three drying temperatures. Also the $\mathrm{MC}$ of lemon verbena 
Table 3. Accuracy of fitting models based on different statistical indices.

\begin{tabular}{|c|c|c|c|c|c|c|c|c|c|}
\hline \multirow{2}{*}{$\begin{array}{l}\text { Temperature } \\
\text { Model name }\end{array}$} & \multicolumn{3}{|c|}{$30^{\circ} \mathrm{C}$} & \multicolumn{3}{|c|}{$40^{\circ} \mathrm{C}$} & \multicolumn{3}{|c|}{$50^{\circ} \mathrm{C}$} \\
\hline & RMSE & $\chi^{2}$ & $R^{2}$ & RMSE & $\chi^{2}$ & $R^{2}$ & RMSE & $\chi^{2}$ & $R^{2}$ \\
\hline \multicolumn{10}{|l|}{$1 \mathrm{~m} / \mathrm{s}$} \\
\hline Two-term exponential & $78 \times 10^{-4}$ & $132 \times 10^{-4}$ & $9,950 \times 10^{-4}$ & $3,078 \times 10^{-4}$ & $120 \times 10^{-4}$ & $9,959 \times 10^{-4}$ & $3,003 \times 10^{-4}$ & $90 \times 10^{-4}$ & $9,920 \times 10^{-4}$ \\
\hline Henderson and Pabis & $3,001 \times 10^{-4}$ & $4,679 \times 10^{-4}$ & $5,890 \times 10^{-4}$ & $3,012 \times 10^{-4}$ & $2,004 \times 10^{-4}$ & $8,907 \times 10^{-4}$ & $3,129 \times 10^{-4}$ & $2,348 \times 10^{-4}$ & $7,987 \times 10^{-4}$ \\
\hline Logarithmic & $2,104 \times 10^{-4}$ & $450 \times 10^{-4}$ & $9,567 \times 10^{-4}$ & $2,978 \times 10^{-4}$ & $658 \times 10^{-4}$ & $9,485 \times 10^{-4}$ & $3,036 \times 10^{-4}$ & $246 \times 10^{-4}$ & $9,568 \times 10^{-4}$ \\
\hline Diffusion approach & 0 & $126 \times 10^{-4}$ & 0 & $2,584 \times 10^{-4}$ & $15 \times 10^{-4}$ & $6,539 \times 10^{-4}$ & $3,002 \times 10^{-4}$ & $17 \times 10^{-4}$ & $5,377 \times 10^{-4}$ \\
\hline Midilli and Kucuk & $87 \times 10^{-4}$ & $19 \times 10^{-4}$ & $9,994 \times 10^{-4}$ & $71 \times 10^{-4}$ & $18 \times 10^{-4}$ & $9,990 \times 10^{-4}$ & $173 \times 10^{-4}$ & $10 \times 10^{-4}$ & $9,995 \times 10^{-4}$ \\
\hline Newton & $2,348 \times 10^{-4}$ & 2.8976 & $5,468 \times 10^{-4}$ & $2,786 \times 10^{-4}$ & $7,655 \times 10^{-4}$ & $8,134 \times 10^{-4}$ & $3,100 \times 10^{-4}$ & $6,754 \times 10^{-4}$ & $8,076 \times 10^{-4}$ \\
\hline Modified Page & $165 \times 10^{-4}$ & $18 \times 10^{-4}$ & $9,896 \times 10^{-4}$ & $3,187 \times 10^{-4}$ & $16 \times 10^{-4}$ & $9,980 \times 10^{-4}$ & $3,658 \times 10^{-4}$ & $38 \times 10^{-4}$ & $9,879 \times 10^{-4}$ \\
\hline Two-term & $3,015 \times 10^{-4}$ & $126 \times 10^{-4}$ & $9,979 \times 10^{-4}$ & $3,006 \times 10^{-4}$ & $66 \times 10^{-4}$ & $9,965 \times 10^{-4}$ & $3,457 \times 10^{-4}$ & $21 \times 10^{-4}$ & $9,891 \times 10^{-4}$ \\
\hline Page & $1,116 \times 10^{-4}$ & $392 \times 10^{-4}$ & $8,746 \times 10^{-4}$ & $1,053 \times 10^{-4}$ & $164 \times 10^{-4}$ & $9,757 \times 10^{-4}$ & $2,256 \times 10^{-4}$ & $244 \times 10^{-4}$ & $9,431 \times 10^{-4}$ \\
\hline Wang and Singh & 0 & 2.998 & 0 & $3,012 \times 10^{-4}$ & $4,358 \times 10^{-4}$ & $5,678 \times 10^{-4}$ & $3,014 \times 10^{-4}$ & $3,178 \times 10^{-4}$ & $7,034 \times 10^{-4}$ \\
\hline \multicolumn{10}{|l|}{$1.5 \mathrm{~m} / \mathrm{s}$} \\
\hline Two-term exponential & $158 \times 10^{-4}$ & $37 \times 10^{-4}$ & $9,974 \times 10^{-4}$ & $3,175 \times 10^{-4}$ & $66 \times 10^{-4}$ & $9,965 \times 10^{-4}$ & $3,149 \times 10^{-4}$ & $96 \times 10^{-4}$ & $9,915 \times 10^{-4}$ \\
\hline Henderson and Pabis & $2,627 \times 10^{-4}$ & $3,737 \times 10^{-4}$ & $6,912 \times 10^{-4}$ & $2,981 \times 10^{-4}$ & $1,381 \times 10^{-4}$ & $8,896 \times 10^{-4}$ & $2,849 \times 10^{-4}$ & $1,986 \times 10^{-4}$ & $8,147 \times 10^{-4}$ \\
\hline Logarithmic & $3,103 \times 10^{-4}$ & $490 \times 10^{-4}$ & $9,649 \times 10^{-4}$ & $3,064 \times 10^{-4}$ & $689 \times 10^{-4}$ & $9,385 \times 10^{-4}$ & $3,127 \times 10^{-4}$ & $303 \times 10^{-4}$ & $9,756 \times 10^{-4}$ \\
\hline Diffusion approach & 0 & $26 \times 10^{-4}$ & 0 & $2,634 \times 10^{-4}$ & $4 \times 10^{-4}$ & $6,939 \times 10^{-4}$ & $2,383 \times 10^{-4}$ & $9 \times 10^{-4}$ & $5,678 \times 10^{-4}$ \\
\hline Midilli and Kucuk & $59 \times 10^{-4}$ & $18 \times 10^{-4}$ & $9,996 \times 10^{-4}$ & $61 \times 10^{-4}$ & $16 \times 10^{-4}$ & $9,993 \times 10^{-4}$ & $162 \times 10^{-4}$ & $4 \times 10^{-4}$ & $9,996 \times 10^{-4}$ \\
\hline Newton & $1,902 \times 10^{-4}$ & 2.7311 & $3,617 \times 10^{-4}$ & $2,652 \times 10^{-4}$ & $7,785 \times 10^{-4}$ & $7,034 \times 10^{-4}$ & $2,652 \times 10^{-4}$ & $7,785 \times 10^{-4}$ & $7,034 \times 10^{-4}$ \\
\hline Modified Page & $145 \times 10^{-4}$ & $12 \times 10^{-4}$ & $9,931 \times 10^{-4}$ & $3,162 \times 10^{-4}$ & $14 \times 10^{-4}$ & $9,976 \times 10^{-4}$ & $3,159 \times 10^{-4}$ & $26 \times 10^{-4}$ & $9,979 \times 10^{-4}$ \\
\hline Two-term & $3,158 \times 10^{-4}$ & $27 \times 10^{-4}$ & $9,964 \times 10^{-4}$ & $3,156 \times 10^{-4}$ & $76 \times 10^{-4}$ & $9,958 \times 10^{-4}$ & $3,161 \times 10^{-4}$ & $17 \times 10^{-4}$ & $9,906 \times 10^{-4}$ \\
\hline Page & $2,108 \times 10^{-4}$ & $291 \times 10^{-4}$ & $9,632 \times 10^{-4}$ & $2,153 \times 10^{-4}$ & $65 \times 10^{-4}$ & $9,963 \times 10^{-4}$ & $2,136 \times 10^{-4}$ & $146 \times 10^{-4}$ & $9,830 \times 10^{-4}$ \\
\hline Wang and Singh & 0 & 2.9576 & 0 & $2,734 \times 10^{-4}$ & $3,594 \times 10^{-4}$ & $6,999 \times 10^{-4}$ & $2,686 \times 10^{-4}$ & $2,735 \times 10^{-4}$ & $7,206 \times 10^{-4}$ \\
\hline \multicolumn{10}{|l|}{$2 \mathrm{~m} / \mathrm{s}$} \\
\hline Two term exponential & $169 \times 10^{-4}$ & $40 \times 10^{-4}$ & $9,886 \times 10^{-4}$ & $3,195 \times 10^{-4}$ & $70 \times 10^{-4}$ & $9,884 \times 10^{-4}$ & $3,019 \times 10^{-4}$ & $86 \times 10^{-4}$ & $9,930 \times 10^{-4}$ \\
\hline Henderson and Pabis & $3,101 \times 10^{-4}$ & $3,897 \times 10^{-4}$ & $6,012 \times 10^{-4}$ & $3,283 \times 10^{-4}$ & $2,581 \times 10^{-4}$ & $7,895 \times 10^{-4}$ & $3,485 \times 10^{-4}$ & $2,316 \times 10^{-4}$ & $7,645 \times 10^{-4}$ \\
\hline Logarithmic & $3,870 \times 10^{-4}$ & $679 \times 10^{-4}$ & $9,438 \times 10^{-4}$ & $3,184 \times 10^{-4}$ & $729 \times 10^{-4}$ & $9,168 \times 10^{-4}$ & $3,547 \times 10^{-4}$ & $403 \times 10^{-4}$ & $9,470 \times 10^{-4}$ \\
\hline Diffusion approach & 0 & $126 \times 10^{-4}$ & 0 & $2,587 \times 10^{-4}$ & $12 \times 10^{-4}$ & $7,839 \times 10^{-4}$ & $2,012 \times 10^{-4}$ & $11 \times 10^{-4}$ & $6,675 \times 10^{-4}$ \\
\hline Midilli and Kucuk & $51 \times 10^{-4}$ & $15 \times 10^{-4}$ & $9,998 \times 10^{-4}$ & $60 \times 10^{-4}$ & $16 \times 10^{-4}$ & $9,995 \times 10^{-4}$ & $174 \times 10^{-4}$ & $9 \times 10^{-4}$ & $9,994 \times 10^{-4}$ \\
\hline Newton & $987 \times 10^{-4}$ & 1.8759 & $5,648 \times 10^{-4}$ & $2,027 \times 10^{-4}$ & $6,548 \times 10^{-4}$ & $8,237 \times 10^{-4}$ & $1,627 \times 10^{-4}$ & $6,775 \times 10^{-4}$ & $8,036 \times 10^{-4}$ \\
\hline Modified Page & $120 \times 10^{-4}$ & $10 \times 10^{-4}$ & $9,945 \times 10^{-4}$ & $2,154 \times 10^{-4}$ & $12 \times 10^{-4}$ & $9,980 \times 10^{-4}$ & $2,127 \times 10^{-4}$ & $16 \times 10^{-4}$ & $9,989 \times 10^{-4}$ \\
\hline Two-term & $2,984 \times 10^{-4}$ & $23 \times 10^{-4}$ & $9,970 \times 10^{-4}$ & $3,026 \times 10^{-4}$ & $56 \times 10^{-4}$ & $9,968 \times 10^{-4}$ & $2,261 \times 10^{-4}$ & $15 \times 10^{-4}$ & $9,936 \times 10^{-4}$ \\
\hline Page & $3,024 \times 10^{-4}$ & $1,247 \times 10^{-4}$ & $9,012 \times 10^{-4}$ & $2,587 \times 10^{-4}$ & $146 \times 10^{-4}$ & $9,087 \times 10^{-4}$ & $2,547 \times 10^{-4}$ & $268 \times 10^{-4}$ & $9,580 \times 10^{-4}$ \\
\hline Wang and Singh & 0 & 2.7547 & 0 & $3,346 \times 10^{-4}$ & $4,337 \times 10^{-4}$ & $5,698 \times 10^{-4}$ & $3,623 \times 10^{-4}$ & $3,765 \times 10^{-4}$ & $6,206 \times 10^{-4}$ \\
\hline
\end{tabular}

Table 4. Arbitrary constant of the Midilli and Kucuk's model for different temperatures and air velocities.

\begin{tabular}{lccccc}
$\mathbf{V}(\mathbf{m} / \mathbf{s})$ & $\mathbf{T}\left({ }^{\circ} \mathbf{C}\right)$ & $\boldsymbol{n}$ & $\boldsymbol{b}$ & $\boldsymbol{k}$ & $\boldsymbol{a}$ \\
\hline \multirow{4}{*}{1} & 30 & 1.126 & -0.00021 & 0.00576 & 0.9913 \\
& 40 & 1.129 & -0.00001 & 0.00904 & 0.9954 \\
& 50 & 1.193 & -0.00076 & 0.01845 & 0.9864 \\
1.5 & 30 & 1.034 & -0.00011 & 0.00875 & 0.9924 \\
& 40 & 1.127 & -0.00000 & 0.00975 & 0.9962 \\
& 50 & 1.184 & -0.00043 & 0.01743 & 0.9878 \\
2 & 30 & 1.128 & -0.00012 & 0.00764 & 0.9986 \\
& 40 & 1.124 & -0.00001 & 0.00986 & 0.9972 \\
& 50 & 1.192 & -0.00102 & 0.02573 & 0.9789
\end{tabular}

leaves was reduced to $10 \%$ w.b. in this dryer. The resulted $\mathrm{MC}$ curves showed that the time of drying and the slope of the curved surface were inversely related.

The dried lemon verbena leaves quality was obtained by determining the EO content of the product after drying in different dryer conditions. Finally, it was observed that the highest $\mathrm{EO}$ content was maintained at a temperature of $40{ }^{\circ} \mathrm{C}$ and air velocity of $1 \mathrm{~m} / \mathrm{s}$. A number of mathematical models were tested for the prediction of drying lemon verbena leaves in this dryer. According to statistical analysis, Midilli and Kucuk's model was selected due to the high coefficient of determination, low RMSE 


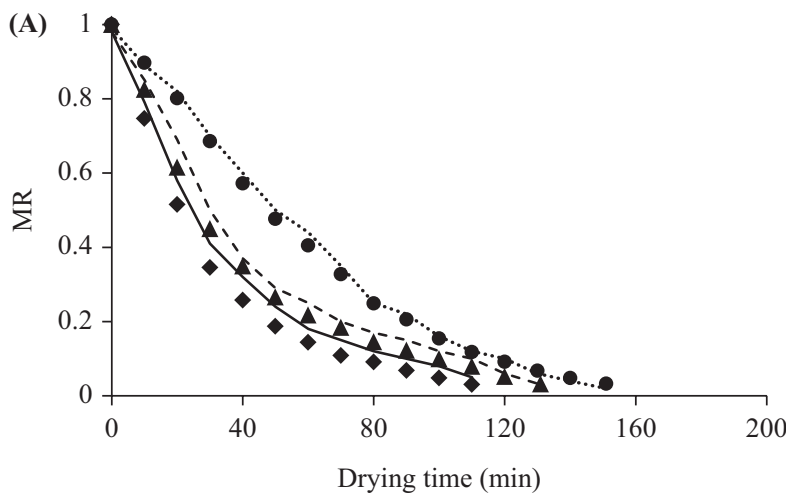

- MR experimental $50^{\circ} \mathrm{C}-\mathrm{MR}$ predicted $50^{\circ} \mathrm{C}$

$\Delta$ MR experimental $40{ }^{\circ} \mathrm{C}----$ MR predicted $40{ }^{\circ} \mathrm{C}$

- MR experimental $30^{\circ} \mathrm{C}$........ MR predicted $30^{\circ} \mathrm{C}$

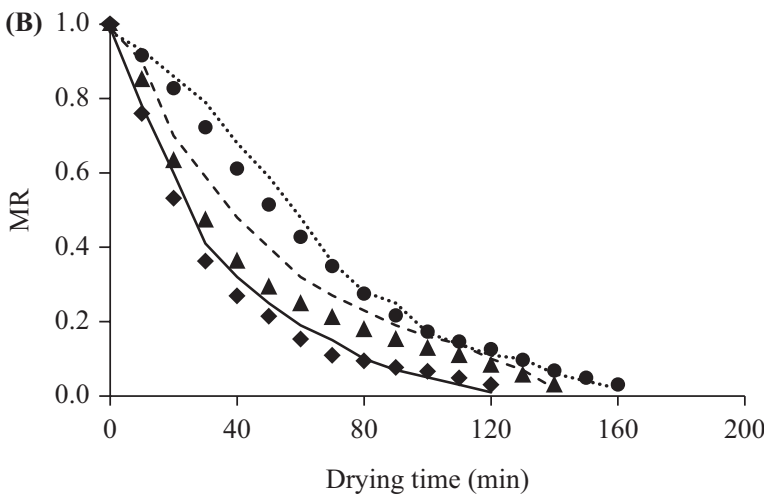

- MR experimental $50^{\circ} \mathrm{C}-$ MR predicted $50^{\circ} \mathrm{C}$

A MR experimental $40{ }^{\circ} \mathrm{C}---$ MR predicted $40{ }^{\circ} \mathrm{C}$

- MR experimental $30^{\circ} \mathrm{C}$........ MR predicted $30^{\circ} \mathrm{C}$

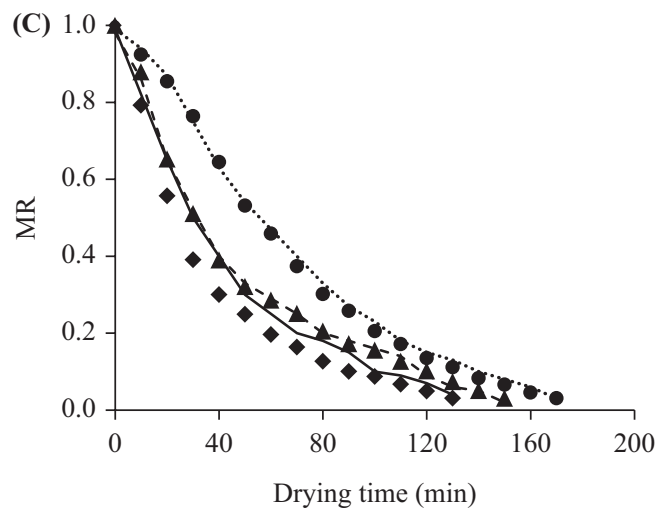

- MR experimental $50^{\circ} \mathrm{C} \longrightarrow$ MR predicted $50{ }^{\circ} \mathrm{C}$

A MR experimental $40{ }^{\circ} \mathrm{C}$ - - - - MR predicted $40{ }^{\circ} \mathrm{C}$

- MR experimental $30^{\circ} \mathrm{C}$........ MR predicted $30^{\circ} \mathrm{C}$

Figure 5. Variation of moisture ratio (MR) experimental and MR predicted with drying time at air velocities of (A) 2, (B) 1.5 and (C) $1 \mathrm{~m} / \mathrm{s}$ and different air temperatures.

and low $\chi^{2}$ and also due to the simplicity of the relationship between kinetics and prediction of drying process for lemon verbena in different air velocities and temperatures. In these models, the amount of $R^{2}$ was above $999 \times 10^{-3}$ and the amounts of RMSE and $\chi^{2}$ were less than $174 \times 10^{-4}$ and $19 \times 10^{-4}$, respectively. Therefore, among the models examined in this article, Midilli and Kucuk's model was selected as the appropriate model for the process of lemon verbena drying in a dryer equipped with a solar pre-heating system for all drying conditions.

\section{Conflict of interest}

The authors declare no conflicts of interest with respect to research, authorship and/or publication of this article.

\section{Compliance with ethical standards}

This article followed all ethical standards for a research without direct contact with human or animal subjects.

\section{Funding}

This research received no specific grant from any funding agency in the public, commercial or not-for-profit sectors.

\section{References}

Abd El-Gaber, A.S., El Gendy, A.N.G., Elkhateeb, A., Saleh, I.A. and El-Seedi, H.R., 2018. Microwave extraction of essential oil from Anastatica hierochuntica (L): comparison with conventional hydro-distillation and steam distillation. Journal of Essential Oil Bearing Plants 21: 1003-1010. https://doi.org/10.1080/09720 60X.2018.1504695

Akhondi, E., Kazemi, A. and Maghsoodi, V., 2011. Determination of a suitable thin layer drying curve model for saffron (Crocus sativus L) stigmas in an infrared dryer. Scientia Iranica 18: 1397-1401. https://doi.org/10.1016/j.scient.2011.08.014

Akpinar, E.K., 2010. Drying of mint leaves in a solar dryer and under open sun: modelling, performance analyses. Energy Conversion 
and Management 51: 2407-2418. https://doi.org/10.1016/j. enconman.2010.05.005

Aral, S. and Beşe, A.V., 2016. Convective drying of hawthorn fruit (Crataegus spp.): effect of experimental parameters on drying kinetics, color, shrinkage, and rehydration capacity. Food Chemistry 210: 577-584. https://doi.org/10.1016/j.foodchem.2016.04.128

Aregbesola, O.A., Ogunsina, B.S., Sofolahan, A.E. and Chime, N.N., 2015. Mathematical modeling of thin layer drying characteristics of dika (Irvingia gabonensis) nuts and kernels. Nigerian Food Journal 33: 83-89. https://doi.org/10.1016/j.nifoj.2015.04.012

Arslan, D. and Özcan, M.M., 2012. Evaluation of drying methods with respect to drying kinetics, mineral content, and color characteristics of savory leaves. Food and Bioprocess Technology 5: 983-991. https://doi.org/10.1007/s11947-010-0498-y

Asekun, O.T., Grierson, D.S. and Afolayan, A.J., 2007. Effects of drying methods on the quality and quantity of the essential oil of Mentha longifolia L. subsp. Capensis. Food Chemistry 101: 995-998. https://doi.org/10.1016/j.foodchem.2006.02.052

Asiru, W.B., Raji, A.O., Igbeka, J.C. and Elemo, G.N., 2013. Mathematical modelling of thin layer dried cashew kernels. Nigerian Food Journal 31: 106-112. https://doi.org/10.1016/ S0189-7241(15)30083-7

Badaoui, O., Hanini, S., Djebli, A., Haddad, B. and Benhamou, A., 2019. Experimental and modelling study of tomato pomace waste drying in a new solar greenhouse: evaluation of new drying models. Renewable Energy 133: 144-155. https://doi.org/10.1016/j. renene.2018.10.020

Baini, R. and Langrish, T.A.G., 2008. An assessment of the mechanisms for diffusion in the drying of bananas. Journal of Food Engineering 85: 201-214. https://doi.org/10.1016/j. jfoodeng.2007.06.035

Benseddik, A., Azzi, A., Zidoune, M.N. and Allaf, K., 2018. Mathematical empirical models of thin-layer airflow drying kinetics of pumpkin slice. Engineering in Agriculture, Environment and Food 11: 220-231. https://doi.org/10.1016/j.eaef.2018.07.003

Bhardwaj, A.K., Kumar, R. and Chauhan, R., 2019. Experimental investigation of the performance of a novel solar dryer for drying medicinal plants in Western Himalayan region. Solar Energy 177: 395-407. https://doi.org/10.1016/j.solener.2018.11.007

Borah, A., Hazarika, K. and Khayer, S.M., 2015. Drying kinetics of whole and sliced turmeric rhizomes (Curcuma longa L.) in a solar conduction dryer. Inf. Process. Agric. 2: 85-92. https://doi, org/10.1016/j.inpa.2015.06.002

Borah, A., Hazarika, K., Khayer, S.M., 2015. Drying kinetics of whole and sliced turmeric rhizomes (Curcuma longa L.) in a solar conduction dryer. Inf. Process. Agric. 2, 85-92. https://doi. org/10.1016/j.inpa.2015.06.002

da Cunha, A.P., Nogueira, M.T., Roque, O.R. and Barroso, J.M.G., 2012. Plantas aromáticas e óleos essenciais: composição e apli $\neg$ cações, Fundação Calouste Gulbenkian publisher, Português, pp. 35-39.

Doymaz, I., 2011. Drying of thyme (Thymus Vulgaris L.) and selection of a suitable thin-layer drying model. Journal of Food Processing and Preservation 35: 458-465. https://doi.org/ 10.1111/j.1745-4549.2010.00488.x

Doymaz, İ. and Karasu, S., 2018. Effect of air temperature on drying kinetics, colour changes and total phenolic content of sage leaves (Salvia officinalis). Quality Assurance and Safety of Crops \& Foods 10: 269-276. https://doi.org/10.3920/QAS2017.1257

Doymaz, I., Tugrul, N. and Pala, M., 2006. Drying characteristics of dill and parsley leaves. Journal of Food Engineering 77: 559-565. https://doi.org/10.1016/j.jfoodeng.2005.06.070

Duffie, J.A. and Beckman, W.A., 2013. Solar engineering of thermal processes, John Wiley \& Sons, pp. 98-100 https://doi. org/10.1002/9781118671603

El-Sebaii, A.A. and Shalaby, S.M., 2013. Experimental investigation of an indirect-mode forced convection solar dryer for drying thymus and mint. Energy Conversion and Management 74: 109-116. https://doi.org/10.1016/j.enconman.2013.05.006

Erenturk, S., Gulaboglu, M.S. and Gultekin, S., 2004. The thin-layer drying characteristics of rosehip. Biosystems Engineering 89: 159-166. https://doi.org/10.1016/j.biosystemseng.2004.06.002

Ertekin, C. and Yaldiz, O., 2004. Drying of eggplant and selection of a suitable thin layer drying model. Journal of Food Engineering 63: 349-359. https://doi.org/10.1016/j.jfoodeng.2003.08.007

Essalhi, H., Benchrifa, M., Tadili, R. and Bargach, M.N., 2018. Experimental and theoretical analysis of drying grapes under an indirect solar dryer and in open sun. Innovative Food Science and Emerging Technologies 49: 58-64. https://doi.org/10.1016/j. ifset.2018.08.002

Ishkeh, S.R., Asghari, M., Shirzad, H., Alirezalu, A. and Ghasemi, G., 2019. Lemon verbena (Lippia citrodora) essential oil effects on antioxidant capacity and phytochemical content of raspberry (Rubus ulmifolius subsp. sanctus). Scientia Horticulturae 248: 297-304 (Amsterdam).

Javed, H.U., Wang, D., Wu, G.-F., Kaleem, Q.M., Duan, C.-Q. and Shi, Y., 2019. Post-storage changes of volatile compounds in airand sun-dried raisins with different packaging materials using HS-SPME with GC/MS. Food Research International 119: 23-33. https://doi.org/10.1016/j.foodres.2019.01.007

Jayatunga, G.K. and Amarasinghe, B., 2018. Mathematical modeling of drying kinetics of black pepper in a spouted bed dryer with and without non porous draft tubes. 2nd International Conference on Trends in Multidisciplinary Business and Economic Research (TMBER), March 23-24, 2018, Sydney Australia, pp. 118-134..

Labed, A., Moummi, N., Aoues, K. and Benchabane, A., 2016. Solar drying of henna (Lawsonia inermis) using different models of solar flat plate collectors: an experimental investigation in the region of Biskra (Algeria). Journal of Cleaner Production 112: 2545-2552. https://doi.org/10.1016/j.jclepro.2015.10.058

Meisami-Asl, E., Rafiee, S., Keyhani, A. and Tabatabaeefar, A., 2010. Determination of suitable thin layer drying curve model for apple slices (variety-Golab). Plant Omics 3: 103.

Mghazli, S., Ouhammou, M., Hidar, N., Lahnine, L., Idlimam, A. and Mahrouz, M., 2017. Drying characteristics and kinetics solar drying of Moroccan rosemary leaves. Renewable Energy 108: 303-310. https://doi.org/10.1016/j.renene.2017.02.022

Motevali, A., Minaei, S., Banakar, A., Ghobadian, B. and Darvishi, H., 2016. Energy analyses and drying kinetics of chamomile leaves in microwave-convective dryer. Journal of the Saudi Society of Agricultural Sciences 15: 179-187. https://doi.org/10.1016/j.jssas. 2014.11.003 
Motevali, A., Minaei, S., Banakar, A., Ghobadian, B. and Khoshtaghaza, M.H., 2014. Comparison of energy parameters in various dryers. Energy Conversion and Management 87: 711-725. https://doi.org/10.1016/j.enconman.2014.07.012

Motevali, A., Minaei, S., Khoshtaghaza, M.H., Kazemi, M. and Nikbakht, A.M., 2010. Drying of pomegranate arils: comparison of predictions from mathematical models and neural networks. International Journal of Food Engineering 6(3): 1556-3758. https://doi.org/10.2202/1556-3758.1889

Movagharnejad, K. and Nikzad, M., 2007. Modeling of tomato drying using artificial neural network. Computers and Electronics in Agriculture 59: 78-85. https://doi.org/10.1016/j.compag. 2007.05.003

Mujaffar, S. and John, S., 2018. Thin-layer drying behavior of West Indian lemongrass (Cymbopogan citratus) leaves. Food Science \& Nutrition 6: 1085-1099. https://doi.org/10.1002/fsn3.642

Omolola, A.O., Kapila, P.F. and Silungwe, H.M., 2018. Mathematical modeling of drying characteristics of Jew's mallow (Corchorus olitorius) leaves. Information Processing in Agriculture 6(1): 109-115. https://doi.org/10.1016/j.inpa.2018.08.003.

Panchariya, P.C., Popovic, D. and Sharma, A.L., 2002. Thin-layer modelling of black tea drying process. Journal of Food Engineering 52: 349-357. https://doi.org/10.1016/S0260-8774(01)00126-1

Pirbalouti, A.G., Mahdad, E. and Craker, L., 2013. Effects of drying methods on qualitative and quantitative properties of essential oil of two basil landraces. Food Chemistry 141: 2440-2449. https:// doi.org/10.1016/j.foodchem.2013.05.098

Rabha, D.K., Muthukumar, P. and Somayaji, C., 2017. Experimental investigation of thin layer drying kinetics of ghost chilli pepper (Capsicum Chinense Jacq.) dried in a forced convection solar tunnel dryer. Renewable Energy 105: 583-589. https://doi.org/10.1016/j. renene.2016.12.091

Saleh, I.A., El Gendy, A.N.G., Afifi, M.A. and El-Seedi, H.R., 2019. Microwave extraction of essential oils from senecio serpens GD Rowly and comparison with conventional hydro-distillation method. Journal of Essential Oil Bearing Plants 22(4): 955-961. https:// doi.org/10.1080/0972060X.2019.1649202
Sari, I., 2018. Evaluation of industrial cosmetic products and replacing them with natural products according to modern, traditional and islamic medicine. Health Biotechnology and Biopharma 1(4): 19-31. DOI: 10.22034/HBB.2018.02

Shamekhi-Amiri, S., Gorji, T.B., Gorji-Bandpy, M. and Jahanshahi, M., 2018. Drying behaviour of lemon balm leaves in an indirect double-pass packed bed forced convection solar dryer system. Case Studies in Thermal Engineering 12: 677-686. https://doi. org/10.1016/j.csite.2018.08.007

Shi, Q., Zheng, Y. and Zhao, Y., 2013. Mathematical modeling on thin-layer heat pump drying of yacon (Smallanthus sonchifolius) slices. Energy Conversion and Management 71: 208-216. https:// doi.org/10.1016/j.enconman.2013.03.032

Torki-Harchegani, M., Ghanbarian, D., Pirbalouti, A.G. and Sadeghi, M., 2016. Dehydration behaviour, mathematical modelling, energy efficiency and essential oil yield of peppermint leaves undergoing microwave and hot air treatments. Renewable and Sustainable Energy Reviews 58: 407-418. https://doi.org/10.1016/ j.rser.2015.12.078

Verma, L.R., Bucklin, R.A., Endan, J.B. and Wratten, F.T., 1985. Effects of drying air parameters on rice drying models. Trans. ASAE 28: 296-301.

Vijayan, S., Arjunan, T.V. and Kumar, A., 2016. Mathematical modeling and performance analysis of thin layer drying of bitter gourd in sensible storage based indirect solar dryer. Innovative Food Science and Emerging Technologies 36: 59-67. https://doi. org/10.1016/j.ifset.2016.05.014

Yogendrasasidhar, D. and Setty, Y.P., 2018. Experimental studies and thin layer modeling of pearl millet using continuous multistage fluidized bed dryer staged externally. Engineering Science and Technology, an International Journal 22(2): 428-438. https://doi. org/10.1016/j.jestch.2018.10.010

Zheng, X., Jiang, Y. and Pan, Z., 2005. Drying and quality characteristics of different components of alfalfa, In: 2005 ASAE Annual Meeting. American Society of Agricultural and Biological Engineers, p. 1. August 13-15, 2005, Hong Kong, pp, 1157-1164. https://doi.org/10.1142/9789812771957_0168. 